Submission for Special Issue 'Transformative Reparations for Sexual Violence Post-conflict: Prospects and problems' edited by Prof Andrea Durbach and Prof Louise Chappell

\title{
When there is No Justice: Gendered Violence and Harm in Post-Conflict Sri Lanka
}

\section{Authors:}

Sara E. Davies (contact author) is an Australian Research Council (ARC) Future Fellow and Associate Professor at the Centre for Governance and Public Policy and Griffith Asia Institute, School of Government and International Relations, Griffith University, Australia. She is also adjunct Associate Professor at Monash University's Gender, Peace and Security Centre (Monash GPS). Sara's research is focused on global health diplomacy and the patterns of systematic sexual and gender-based violence in Asia Pacific conflictaffected countries. Sara is co-editor with Jacqui True of the Oxford Handbook on Women, Peace and Security (Oxford University Press, forthcoming).

Address: Center for Governance and Public Policy

Griffith University

Building N 72

University Road

Nathan QLD 4111

Australia

E: sara.davies@griffith.edu.au

T: @DaviesSaraE

Jacqui True is Professor and Director of Monash University's Centre for Gender, Peace and Security (Monash GPS) in the School of Social Sciences at Monash University, Australia. She is also an Australian Research Council (ARC) Future Fellow and a Global Fellow, Peace Research Institute (PRIO), Oslo. Her current research is focused on understanding the political economy of post-conflict violence against women and the patters of systematic sexual and gender-based violence in Asia Pacific conflict-affected countries. She is co-editor with Sara Davies of the Oxford Handbook on Women, Peace and Security (Oxford University Press, forthcoming).

Address: School of Social Sciences

Monash University

Building 11

Clayton Campus

Clayton VIC 3800

Australia

E: Jacqui.true@monash.edu

T: @Jacqui.True

\section{Funding details:}

This work was supported by the Australian Research Council under Grant DP140101129. 


\title{
When there is No Justice: \\ Gendered Violence and Harm in Post-Conflict Sri Lanka
}

\begin{abstract}
Reparative measures for conflict-related sexual and gender-based violence (SGBV) attend to the practical needs of victims while also addressing the long-term structural conditions that led to the violence and often endure after conflict. Over the last decade, transitional justice has sought to address high levels of impunity for SGBV, while also addressing the long-term structural conditions causing and exacerbating it. Here we study the case of Sri Lanka where crimes have been committed during and after during the civil war (1983-2009) but a transitional justice mechanism to redress them is unlikely to be established. In such a situation of impunity can gender-sensitive approaches to SGBV prevention still be promoted to ensure its nonrecurrence? We closely examine post-conflict Sri Lanka and women's ongoing experiences of multiple forms of insecurity and violence to highlight the relationship between enduring structural gender inequalities and reparative justice. Bridging human rights and political economy approaches, we argue that addressing gender inequalities in access to resources and public space are essential to prevent further gender-based violence and structural harms in conflict-affected countries like Sri Lanka.
\end{abstract}

Keywords: post-conflict, sexual and gender-based violence, gender inequality, human rights, transitional justice.

\section{Introduction}

Reparative measures for sexual and gender-based violence (SGBV) seek to address the practical needs of victims while also addressing the long-term structural conditions that led to the violence and the perpetuation of gender harms after conflict. Significant attention has been paid to the few cases where reparative justice has been attempted in response to SGBV crimes over the last decade, ${ }^{1}$ but what of the contemporary conflict situations where SGBV has occurred but there is little likelihood of a transitional justice mechanism being established to redress them? How can gender-sensitive post-conflict transformative approaches be promoted to ensure the non-recurrence of sexual violence and of conflict? To explore this question we consider the case of Sri Lanka and the patterns of SGBV during the 30-year civil war (1983-2009) between the Government and the LTTE - Tamil Tigers. In this 
paper we explore the occurrence of SGBV during the final stages of the conflict and after the war.

Grave acts of war crimes and crimes against humanity, including SGBV, were committed by both the Sri Lankan armed forces and the Tamil Tigers (LTTE). ${ }^{2}$ The first UN Secretary-General High Level Panel commissioned to report on violence committed by both the Sri Lankan armed forced and LTTE noted that crimes of sexual violence were 'greatly under-reported' due to 'cultural sensitivities and associated stigma [which] often prevented victims from reporting such crimes, even to their relatives'. ${ }^{3}$ The Office of the High Commissioner for Human Rights (OHCHR) Commission of Inquiry into Sri Lanka report (released 2015) found that the Sri Lankan government had continually failed to investigate, pursue or prosecute these gross violations of the human rights committed by the LTTE and their own security forces (police and armed forces). In the case of SGBV crimes, the OHCHR report found that female civilians and LTTE combatants (male and female) were deliberately targeted for sexual violence in the final stages of the conflict by Sri Lankan armed forces. ${ }^{4}$ In the immediate post-conflict period, returning displaced women, former LTTE combatants (men and women), and human rights advocates were subjected to sexual violence and harassment in their homes, in administrative buildings, in prisons and military compounds. ${ }^{5}$ To date, the Sri Lankan government response to allegations of wartime rape and other acts of sexual violence has fallen far short of international legal standards on transitional justice, due process, and investigation. ${ }^{6}$ The 2013 UN Secretary-General report on conflict-related security violence noted that during and immediately after end of the civil war, of the 375 reports of conflict-related sexual violence which allegedly occurred between 2007 and 2012, the Sri Lankan government investigated just 11 cases. ${ }^{7}$ As of 2015, the number of conflict-related sexual violence cases investigated has risen to 39 with only one conviction of four soldiers for gang rape of two Tamil women in $2010 .^{8}$

In the post-conflict era, sexual abuse and harassment against returning women are a frequent occurrence in the conflict-affected areas in the North and East provinces of Sri Lanka. As stated in the most recent UN Secretary-General report on conflictrelated sexual violence 'those displaced from conflict lead highly circumscribed lives in militarized zones, such as in northern Sri Lanka, due to an ever-present threat of 
sexual assault'. ${ }^{9}$ Post-conflict economic marginalisation and inequality coupled with widespread impunity for war crimes and human rights violations prompted the Oakland Institute (2015) to describe Sri Lanka as experiencing a second 'silent war'. ${ }^{10}$

The election of a new government in 2015 presented a new opportunity for more inclusive post-conflict peace and economic development in Sri Lanka. Civil society and rights based groups such as FOKUS, the Centre for Policy Alternatives (CPA), and the International Truth and Justice Project (ITJP) have called for a gendersensitive approach to future transitional justice mechanisms, including a call for conflict-related sexual violence crimes to be investigated by a government-appointed prosecutor. ${ }^{11}$ To date, however, no prosecutor has been appointed to investigate the war crimes and crimes against humanity committed by the Sri Lankan armed forces and the Tamil Tiger forces (LTTE). ${ }^{12}$

In post-conflict Sri Lanka, pervasive fear, stigma, and calls for national unity, create strong incentives to not report experiences of violence; as a result, state and non-state institutions continue to lack capacity to respond to allegations of sexual violence. The lack of institutional acknowledgement of sexual violence crimes associated with the war reflects a perpetual cycle of acceptance and tolerance of gender-based violence in Sri Lankan society. In Sri Lanka, the UN Population Fund (UNFPA) estimates one out of four females have been sexually abused by the time they reach $18 ; 44 \%$ of female university students have experienced sexual harassment on campus; over $60 \%$ of women surveyed in Colombo district have experienced sexual harassment at their workplace. ${ }^{13}$ In 2012, over 90 per cent of women surveyed reported sexual harassment in public spaces and on public transport. At the provincial level, womanheaded households (where there is no male 'breadwinner' and widowed/unmarried women face discriminatory laws and practices in land inheritance) report they are commonly approached for sexual favours in exchange for assistance or protection from the government and police sectors. ${ }^{14}$ Sexual torture of men and women in prisons is commonplace. ${ }^{15}$ Early marriage of girls in minority communities, a practice during the war to prevent LTTE recruitment, has continued in the East and North provinces since the end of the conflict and is visible in the high rates of teenage pregnancy (particularly in Eastern province) ${ }^{16}$ At the same time there are widespread, 
everyday patterns of domestic violence, family violence, and community level discrimination of women across all ethnic communities. An international survey shows that less then 10 per cent of rape cases have been successfully prosecuted in Sri Lanka and that 60 per cent of men feel entitled to sex without prior permission of partner. ${ }^{17}$

Gender inequality has a long history in Sri Lanka that pre-dates the war and is present among the Sinhalese majority and Muslim and Tamil minority groups. ${ }^{18}$ Violence against women in Sri Lanka is endemic and largely tolerated by the state system. The culture of impunity for sexual and gender-based violence is maintained by the Sri Lankan government's failure to collect baseline data on any type of violence against women. 'Gender-based violence' is the preferred lexicon in Sri Lankan government reports and, other than those published by civil society reports, official reports on 'sexual violence' are rare in Sri Lanka. ${ }^{19}$ Since the end of the conflict, the few existing reports of sexual violence available suggest that women in the North and East provinces experience the highest levels of personal insecurity, violation of bodily integrity, and sexual violence. ${ }^{20}$

There has been no return of conflict and the election of a new government in 2015 . President (Siresena) has acknowledged that women and girls in war-affected regions remain vulnerable to community and state level violence. ${ }^{21}$ Silence and impunity continues however, for the sexual violence crimes committed during and after the war. $^{22}$ Were these crimes to be investigated, there is no doubt that social, racial and political tensions would be tested. Given this situation some have suggested that transitional justice mechanisms may deliver accountability but not repair the harm caused by the Sri Lanka's history of conflict-related sexual violence. ${ }^{23}$ Pending the creation of such a mechanism, what alternative post-conflict reforms are available to readdress the harms caused by SGBV committed during the war? Addressing the economic and gender inequalities that fuelled the acceptability of gender based violence and harm in the first place, and lead to some being more vulnerable to this violence, has been suggested as an alternative response to ensure the non-recurrence of SGBV and of conflict. ${ }^{24}$ 
We explore this argument in three parts. First, we provide a background on the Sri Lanka war highlighting the gendered nature of the conflict and how sexual and gender-based violence was part of its dynamics. Second, we examine the political, economic and military dimensions of the post-conflict era and show how systemic gender discrimination leads to pervasive SGBV. Third, we consider how to reconcile the failure of successive governments to end the impunity for conflict-related SGBV with the need to redress the political and economic marginalisation of women, particularly of minority women and girls. We assess current proposals by the Sri Lankan government for transitional justice mechanisms and argue that any future truth, justice, and reparations mechanisms should have a gender justice programme at their core. This programme for gender justice must be political economy-centred, providing access to resources and ensuring political and economic equality, as well as recognising the gendered nature of past harms. Moreover, irrespective of whether a transitional justice mechanism is introduced, implementing an economic reparative approach is possible and may provide greater opportunities for women long disenfranchised and harmed by the war to rebuild their lives than a transitional justice response by itself.

\section{Gendered dimensions of the Sri Lanka civil war}

Sri Lanka experienced a protracted civil war between 1983 and 2009 in which a great number of civilians died. The Uppsala Conflict Data Program estimates over $60,000^{25}$ while the 2015 OHCHR Investigation on Sri Lanka suggested it was 'likely [that] tens of thousands, lost their lives'. ${ }^{26}$ The primary actors in the three decades long internal conflict were the LTTE, from the North and East provinces of Sri Lanka, and the Government of Sri Lanka. The LTTE's objective was to create an independent Tamil Eelam state, which involved the removal of the Muslim population (Sri Lanka's second largest minority group) and Sinhalese from the North and East provinces. ${ }^{27}$ It was a 'ruthless and formidable military organization' ${ }^{28}$ and targeted anyone (including Tamils) who opposed its sole objective to create an independent Tamil state. The armed group had forcibly recruited children to be combatants, including girls, used abduction and extortion practices, committed suicide attacks, political assassinations and arbitrary executions, and regularly located military units and training grounds within civilian territory using women and children as 'human 
shields' to prevent the targeting of their military facilities. ${ }^{29}$ This is not the only conflict waged in Sri Lanka since its 1948 independence but it was the longest and most violent with human rights violations committed by both parties throughout the conflict. $^{30}$

The conflict ended in May 2009 after an intense period of fighting. The Sri Lankan government mobilised 300,000 troops to enter the North province (LTTE stronghold territory) to wipe out the LTTE and end the civil war. An estimated 40,000 civilians were killed due to shelling and direct fire between and some of the worst casualties and displacement during the entire thirty-year war inflicted on the North and East provinces. ${ }^{31}$ When the Sri Lankan army advanced from the South and the East, 300,000 civilians were herded into a three-kilometre stretch of land, which came under attack from both sides. Between 2008 and 2009 300,000 people were displaced in addition to the 520,000 previously displaced in earlier battles in the $2000 \mathrm{~s}^{32}$

Among the casualties and displacement during this time were alleged atrocities that included rape and other sexual violence perpetrated on combatants and civilians. In relation to patterns of $\mathrm{SGBV},{ }^{33}$ most documented incidents concern allegations against the Sri Lanka government security forces (military and police). ${ }^{34}$ However, the LTTE were well known to have abducted girls for forced marriage as well as to fight and forcibly detained women and children as 'human shields'. Families were threatened and beaten if they refused to hand over their children to the LTTE, and there was a 'pattern' in the North of the forced marriage of children to avoid LTTE conscription. ${ }^{35}$

During the intense months of battle in 2008 and 2009, humanitarian actors ${ }^{36}$ reported sexual violence, torture, enforced disappearances and extrajudicial killings against LTTE cadres and suspected LTTE combatants being held by the Sri Lankan security forces. ${ }^{37}$ While in government-controlled camps, civilians were subjected to rigorous screening procedures with women being forced to remove their clothing to partial or complete nudity, often in front of members of the opposite sex. Females were reportedly humiliated by male soldiers who would watch them undress, poke their breasts with rifle barrels and, at times, record videos or photographic images of the naked women on their mobile phones. 
Rape became a common 'tool' used by the Sri Lankan military and police during and after the final stages of the war to gather intelligence on the LTTE network, intimidate LTTE members and sympathizers, and to secure bribes from family members to release whoever was in custody. ${ }^{38}$ A Human Rights Watch report notes that ethnic Tamil men and women as well as Sinhalese and Muslims detainees were subjected to sexual violence in prison for sympathies to the LTTE and/or anti-government sentiment. ${ }^{39}$ Allegations of SGBV inside the internally displaced camps, especially the largest camp: Manik Farm, were also reported immediately after the war. ${ }^{40}$ Numerous, corroborated reports stated that women and young girls being raped at night, whilst going to the bathroom, and whilst collecting firewood. Sexual favours were allegedly demanded by soldiers and the police in return for access to food rations, dry quarters, quarters closer to the toilet, and early release. In addition to the torture and rape of detained men and women, the Sri Lankan security sector has been accused of committing SGBV crimes post-conflict, including rape on women returning from displacement camps in North and East provinces.

In the immediate aftermath of the conflict, the Sri Lankan government faced little international condemnation for its actions during and after the conflict. UN member states did not raise the situation in Sri Lanka before the Security Council, the General Assembly or the Human Rights Council with the result that these bodies were not briefed on the situation nor was it added to their agenda. ${ }^{41}$ Inside Sri Lanka, those who attempted to draw attention to the alleged violations - journalists, civil society actors, and opposition politicians - were then targeted for violence themselves. ${ }^{42}$ In 2010 the UN Secretary-General Ban Ki-Moon established a Panel of Experts, chaired by Marzuki Darusman, to investigate accountability for conduct during the final months of the conflict. ${ }^{43}$ This report, released in April 2011, ${ }^{44}$ found that the Sri Lankan government was 'unable and unwilling' to satisfy the international standards of independence and accountability for investigating the allegations concerning the Sri Lankan government and the military during the final stages of the conflict (20082009). The 'Darusman report' stressed the gravity of the human rights abuses alleged to have been committed by Sri Lankan military and police in the North and East provinces. $^{45}$ 
This report was followed by, inter alia, the Human Rights Watch report (2013), ${ }^{46}$ the International Truth \& Justice Project (ITJP) reports $(2014,2015),{ }^{47}$ and the OHCHR report (2015). ${ }^{48}$ They all refer to the entrenched impunity for grave acts of torture and sexual violence committed primarily by Sri Lanka military and police. Despite the peaceful election of a new government in 2015, this culture of impunity has prevailed for those who won the war in 2009.

A year after the war, in 2010, the Rajapaska government introduced a reconciliation process, The Lessons Learned and Reconciliation Commission (LLRC). The LLRC however, was not set up to be a fact finding mission nor was it given powers to act independently of the government, pursue individual accountability or judicial follow up of allegations of human rights abuses by military and police. ${ }^{49}$ The Presidentappointed members on the LLRC strengthened reluctance of some to report, seeing it as an 'institutional barrier imposed by the Sri Lankan government to block effective reporting and investigation of rape cases' ${ }^{50}$ Likewise, the OHCHR report stated that a large number of sexual crimes were committed but were not reported due to fear of reprisals, stigma and trauma. ${ }^{51}$ After the release of the OHCHR report detailing some of these crimes, ${ }^{1}$ four soldiers were found guilty and sentenced to 25 years each for raping a Tamil woman in a displacement camp (in Vishwamadu, Kilinochchi). ${ }^{52}$

This appears to be the first and last case taken seriously by the Sri Lanka military. Both the former and new government administrations have stated that they will not adopt the OHCHR call for a special hybrid international court to try war crimes by both the LTTE and Sri Lankan armed forces. We discuss the justification provided for this decision and its consequences in the last section of this paper. In the next section we examine how political, economic and military dimensions of the postconflict period have heightened gender discrimination and perpetuated systematic sexual and gender-based violence.

\section{Post-conflict militarization, violence and economic boom.}

\footnotetext{
${ }^{1}$ Some of these cases involved gang rape; the majority of victims were under the age of 18 ; and the majority of the victims were Sinhala, with 12 and 2 cases, respectively, involving Tamil and Muslim victims. The 58 alleged perpetrators of these 39 cases were: 32 from the Sri Lanka Army; 13 police; one from police Special Task Force; one from Sri Lanka Navy; and 11 from the Civil Defence Force (OHCHR, A/HRC/30/CRP, 119, 126).
} 
Announcing his "Vision for the Future" in 2010, Sri Lankan President Mahinda Rajapaksa stated: 'the Sri Lankan people are now awaiting the victory in the 'economic war' in a manner similar to our victory in the war against terrorism. ${ }^{, 53}$

In so doing, he explicitly linked the violence inherent in post-war economic reconstruction to the violence of the conflict. ${ }^{54}$ Over seventy per cent of the growth in GDP between 2004 and 2013 is attributed to the growth in non-tradeable sectors (e.g. construction, transport, utilities) fueled by Chinese-financed debt-driven infrastructure spending. ${ }^{55}$ The feminized agricultural and export garment industry sectors have not benefitted from government subsidies, with the latter being profitable in part due to low-cost female labour. In the North and East, both the Rajapaska and current Sirisena governments ignored recommendations from the LLRC and have maintained a strong military presence in the Jaffna Peninsula with the military appropriating land for use in military-run farms, hotels and other enterprises. ${ }^{56}$ Sri Lanka has been coined a 'middle income country at peace' by the World Bank ${ }^{57}$ with its high growth rates and low inflation. However, this catchphrase does not capture the lingering failure to address conflict and post-conflict gendered human rights violations or the inequity of post-conflict economic boom. The continuity of violence is particularly evident with respect to the structural and physical violence against minorities, political opposition and women.

Continued militarization of the Northern and Eastern provinces has altered but not reduced minority women's vulnerability to sexual and gender-based violence. Some estimates put the ratio of military to civilians in the North at 1 soldier to 5-8 civilians. ${ }^{58}$ The military occupies large portions of land with control over agriculture, tourism and other development projects in the Northern and Eastern provinces. ${ }^{59}$ The LLRC was much criticised for its lack of independence from the executive (see below), but even this report stressed the immediate needs of women, especially widows who most often have become heads of their households, must be met. These immediate needs include economic livelihood assistance to reduce the immense economic hardships and poverty under which they and their families are living at present. ${ }^{60}$ Women who live close to military bases or employed on farms, in hotels or shops owned by the military experience high rates of sexual harassment and abuse. ${ }^{61}$ Perpetrators of such violence are not restricted to the military, women who work in 
military-owned or controlled businesses face retaliation from their local communities for 'colluding' with the military. Some have even been accused of prostituting themselves to the Sri Lankan army and experienced isolation and stigma for this 'collusion'.

Female ex-combatants, war widows of LTTE soldiers, and women and girl returnees have been especially targeted in these heavily militarised zones. Across Sri Lanka, $23 \%$ of households are female-headed and more than $50 \%$ of these are widows. ${ }^{62}$ In the North and East provinces, at least $60 \%$ of returning women are the only income provider for their household and have not always been able to return to their land or village. Their children and themselves may be outcasts in their new location, they may have had to live under emergency rule on their return, where access to wages, land, housing, and identity cards requires the cooperation of military, police and the local administration. ${ }^{63}$ Women have had to claim war compensation or their rights to access land at the military's headquarters, which was the only functioning governing authority immediately after the war in conflict-affected areas. ${ }^{64}$

'Api anaarakshithay' ('we lack security') is a constant refrain by war widows. ${ }^{65}$ The Report of the Leader of the Opposition's (Hon. Ranil Wickremesinghe) Commission on the Prevention of Violence against Women and the Girl Child (2014), documents the rape of girls by military officers noting that few military personnel have been prosecuted, witnesses have been harassed or forced to leave the country, and impunity is pervasive, particularly if the offenses were committed by the state security forces. ${ }^{66}$ The inquiry also documented coercive and transactional sex as survival strategies for women and girls in the context of militarization. Members of the Commission heard complaints from several women's organisations that 'women are afraid to take any action in cases of sexual abuse due to fear of reprisals and as they do not get access to any form of support'. They concluded that impunity 'is still extremely pervasive in post-war Sri Lanka' and 'prevents women from reporting incidents of violence against them'. ${ }^{67}$ Women and girls are targeted for violence as embodiments of minority group identity and because gendered cultures of stigma and shame generalizes their oppression and punishment across their families and communities. ${ }^{68}$ 
Women and girl returnees are also vulnerable within their community - where women without male protection at night or dowries to protect their daughters from forced or unsuitable marriages are considered 'easy prey' ${ }^{69}$ There is also a tradition of early marriage in Tamil society given the need to marry young girls, in particular, to avoid LTTE conscription. However, in Tamil society, female widows are considered unlucky. They are often also economically vulnerable which heightens their risk of coercive and transactional sex to secure essential resources. Muslim women, also affected by the war face similar inequalities caused by displacement, early marriage, and discrimination by both Sinhalese and Tamil populations. In sum, the postconflict situation has hardly improved the daily insecurity for women in the North and East.

For the thousands of women who lost their husbands and other family members during the armed conflict, 'post-conflict' has brought new breadwinning responsibilities to support their families economically. The 2012-13 Household Income and Expenditure Survey (Department of Census and Statistics) estimated that 1.2 million or 23.5 per cent of all households across the country are female-headed (FHH) (either married, never married, separated, divorced or widowed).$^{70}$ According to the Ministry for Women's Affairs and Child Development there are more than 40,000 war widows in the Northern Province and 42,565 widows in the Eastern Province, whose husbands were either killed or disappeared during the war. ${ }^{71}$ The high presence of FHH in the Northern and Eastern provinces is likely attributable to the war because women are the primary providers in more families than before the war. $^{72}$ In the aftermath of the war this has created a number of problems for women already facing local stigma as female-headed households. First, the missing in action is in the thousands and few women have documentation to prove the death of their husband to facilitate access to land, compensation, even remarry. Second, widows are often not able to receive the targeted social assistance benefit, "Samurdhi". Despite meeting the poverty-based criteria, they do not have the necessary documentation vis a vis the state to take into account the missing person in household. ${ }^{73}$ Widows are also vulnerable to land grabs for this same reason. ${ }^{74}$ Finally, these women are especially economically vulnerable due to all of the above as well as the lack of economic opportunities in the regions where there is entrenched gender discrimination in employment as discussed below. 
Across Sri Lanka, economic opportunities for women, as seen in their formal labour market participation, have remained stable despite increased economic growth in the post-war period. According to the Labour Force Survey Annual Report 2014, while the all-island labour force participation rate of women was 35 per cent (compared with 75 per cent for men), the participation rate of women in the conflict-affected Jaffna district was 29 per cent (where women are 53 per cent of the population) with just 15 per cent of women employed in the Mannar district (the lowest in the country). Quarterly labour surveys ceased due to the war between 1990 and 2011. As such, there is no baseline on women's labour market participation in the North and East provinces. Since surveys resumed in these provinces in 2011, they show a massive increase in women's employment, six times the average employment growth rate in the country, and set against more modest increases in men's employment in this region. $^{75}$

However, women's unemployment has been significantly higher than men's unemployment, ranging from six to 17 per cent compared with below six per cent for all districts in conflict-affected provinces between 2012 and 2014. Despite women taking on previously male roles in the workforce during the war, creating more equitable gender divisions of labour, discrimination against working women has (re)emerged in the post-conflict period with far higher rates of casualization of labour for women than men. In a recent survey of 258 workers in Jaffna, the largest city in the North, 85 per cent of women respondents did not have an employment contract. ${ }^{76}$ Women face limited income opportunities due to their lack of education and experience culturally, even village-specific, gender divisions of labour that restrict the jobs and the decent work available to women in male-dominated sectors such as fishing and agriculture but also in construction and garment factories. ${ }^{77}$

Providing the opportunity for female-headed households to create and sustain their own independent income would go some way to end the stigma and injustice suffered by women in North and East Sri Lanka. The estimated 3,000 former female combatants (many of whom were forcibly recruited as child brides) in the North and Eastern provinces are particularly subjected to abuse and harassment. They are typically shunned by communities and even their own families who consider them a 
security threat and not marriageable. ${ }^{78}$ Gender-segregated rehabilitation programs delivered by the Sri Lankan army have retrained female ex-combatants but in traditionally low-income feminine occupations - beauty therapy, sewing for the garment industry, handicrafts and selling products to tourist resorts in an apparent effort to restore the post-war gender order as well as economic recovery. ${ }^{79}$

Economic boom since the war's end has done very little to resolve the structural inequalities and grievances based on ethnicity, caste and gender with respect to land, resources, public employment, education and skills in the North and East provinces. The economic gap coupled with the impunity gap for the gender and human rights violations committed in the final stages and after the war continues to fuel the country's climate of impunity for SGBV. War widows, female heads of households, female ex-combatants, employed women and girls are especially at risk due to their often impoverished contexts, lack of education as a result of the war and their lack of opportunities in post-war economic reconstruction and development plans. Given the social, ethnic and religious tensions that continue to be associated with the victims and perpetrators of sexual violence in post-conflict Sri Lanka, the next section discusses what a gender-responsive approach to post-conflict development and justice, that addresses the continued insecurity of minority women in particular, might look like.

\section{National and International Responses to Gender Justice}

The Sri Lankan government response to gender discrimination and to human rights violations such as SGBV has been extremely limited until recently. However, in January 2015, Maithripala Sirisena, a former Deputy to President Rajapaksa, led a new opposition party to victory in the national elections on a promise of 100-day work programme of significant governance reform. On assuming power, Sirisena promised that new laws to prevent abuse of women, and that 'measures would be taken to ensure that women and children can live without fear in Sri Lanka' ${ }^{80}$ The government's maiden economic policy statement claimed that one million new jobs 'with good wages' would be created in the next five years of this government. This is 'the first time in Sri Lanka any politician has tied employment generation to decent 
wages'. ${ }^{81}$ They have introduced a national action plan to reduce gender-based violence, which the government sees as a barrier to economic development through women's participation in the labour market. As well, the government aims to address women's empowerment in the war-affected provinces through targeted development interventions.

Governance reforms have been carried out to ensure the impartiality of police and justice institutions and to reduce Presidential powers in the Constitution. Police and security sectors are devolving and there has been some progress with security sector reform, rule of law and freedom of expression. ${ }^{82}$ There is a new multi-sectoral national framework and action plan on gender-based violence coordinated through the Ministry of Women and Child Affairs. In addition, a national secretariat for the empowerment of widows and women headed families has been established to be the main resource centre in providing services mainly for widows and women-headed households in North and Eastern Provinces. ${ }^{83}$ Furthermore, of potential significance for these provinces is a provision to the Local Authorities Act for women to make up 25 per cent of representatives in local government, and 15 per cent in Provincial Council and Parliament. ${ }^{84}$

However, despite the pledges within 'A New Sri Lanka for Women' that were to address the particular lack of equity faced by women in North and East provinces, the Sirisena government has not made progress in the areas that affect these women most: low rates of investigation and prosecution for SGBV; economic and physical vulnerability in the garment sector; and economic and employment marginalisation in general. According to the Verite Report, 'The President's Pledges to Women January 2016: A review of the promises and progress made in President Sirisena's pledge', there has been 'no progress' on law enforcement to address mounting sexual offences against both women and children, on state support for better lodging facilities for women in the apparel sector, and on legal recognition and protection for domestic workers and women employed in the informal sector. ${ }^{85}$

The threat of SGBV by the Sri Lanka military - and by civilians - has continued women's insecurity in these provinces, but the new government has consistently denied that there was any systematic use of sexual violence amounting to war crimes 
by its security forces during and after the conflict. As such under this government, the likelihood of an prosecutor's office being set up to investigate these crimes remains as unlikely as the UN OHCHR recommendation to create a special hybrid court to try individuals for war crimes and crimes against humanity. ${ }^{86}$ Calls for a government appointed prosecutor to specifically investigate the evidence of war crimes pertaining to sexual violence (committed by both the Sri Lankan military and LTTE) have also been refused by the Siresena-led government. Continually the Sirisena government has said that rather than transitional justice they have prioritized development assistance to the North and East to catch up with post-conflict economic boom in Sri Lanka. ${ }^{87}$

However, efforts by the current government to establish transitional justice mechanisms in tandem with economic development programmes that are effectively "reparations" are now at an incipient stage. The new government co-sponsored a UN Human Rights Council Resolution on the beleaguered and much criticised LLRC in September 2015. ${ }^{88}$ The resolution lists 36 measures that the government was to implement to meet international standards of accountability, human rights, justice and transparency, of which only 20 per cent have been met. ${ }^{89}$ The Prime Minister appointed a Consultation Task Force on Reconciliation Mechanisms in January 2016. It is tasked with consulting members of the public on the processes and mechanisms for reconciliation in Sri Lanka 'to seek truth, ensure accountability for human rights violations and provide measures for redress'. ${ }^{90}$ Members of Zonal taskforces to consult around the country were appointed at the end of May 2016 with six to eight members selected from 15 geographical zones on the basis of gender balance, ethnic and religious representation, members' leadership roles in society and experience in working on issues related to human rights, reconciliation and peace. ${ }^{91}$ The Taskforce invited submissions from the public on the design of structures, processes and measures to seek truth and justice, ensure accountability and offer redress over a period of three months. ${ }^{92}$ The Government is still considering four institutional mechanisms in particular to achieve these goals: 1) An Office of Missing Persons ${ }^{93}$; 2) A Truth, Justice, Reconciliation and Non-Recurrence Commission; 3) A Judicial Mechanism with a Special Counsel and; 4) An Office of Reparations. A Secretariat for Coordinating Reconciliation Mechanisms within the Prime Minister's Office, formed by the Cabinet of Ministers, is officially overseeing the design and 
implementation of Sri Lanka's reconciliation mechanisms and may take into account the recommendations of the Consultation Taskforce.

Four forms of justice are highlighted in the Consultation Taskforce on Reconciliation Mechanisms' Interim Report on the Office of the Missing Persons Bill and Issues Concerning the Missing, the Disappeared and the Surrendered. They are: gender security, reparations, economic justice and participatory justice. ${ }^{94}$ Gender Security involves bringing security to women and girls living in militarised areas in particular and promoting a culture of gender equality that aims to end patriarchal norms. ${ }^{95}$ Reparative justice is needed to redress the unequal compensation between the families of Sri Lankan army members and of missing, disappeared or surrendered minorities, to provide long-term support to these families which are often single, femaleheaded. ${ }^{96}$ Economic justice is crucial for the right to non-recurrence given the conditions of structural violence disproportionately affecting minority women and girls discussed in part three of this article. ${ }^{97}$ Participatory justice refers to the need for citizens' trust in the government to be cultivated and to enable women to voice their security concerns and lived realities. ${ }^{98}$

Given successive governments reluctant to pursue a heavily judicial transitional justice response, the equal weighting of gender security, reparations, economic development and preparatory justice possibly presents an alternative Sri Lanka context-specific understanding of justice necessary to achieve reconciliation and to transform the structural and physical violence currently experienced by many femaleheaded households, former female combatants, rural women as well as SGBV survivors

However, the likelihood of prosecuting individuals for committing war crimes and crimes against humanity is low while, the general prevalence of sexual violence in Sri Lanka remains difficult to measure due to the lack of consistent and transparent data collection methods. One small breakthrough consistently promoted in any discussion of post-conflict gender justice in Sri Lanka has been the emphasis on the need for all Sri Lankans to be economically independent and empowered. The Sri Lankan Government's national action plans on the economic empowerment of women, on the prevention of gender-based violence against women and girls, and on women-headed 
households should be connected by a strong implementation framework. Of course these frameworks needs to place women's socio-economic rights at their centre, and to recognise that they may be the only protection available to ensure non-recurrence of violence at work, at home, and in public spaces, to ensure the non-recurrence principle.

The state's role is crucial in reconciliation and transitional justice - and less explored in this article but equally important in post-conflict investment boom - donor state and foreign investors are uniquely placed to press upon the Sri Lankan government's gender discrimination and human rights record. ${ }^{99}$ Moreover, we suggest that the usual transitional justice mechanisms must be accompanied to a broader commitment to address gender security, economic justice and participatory justice within Sri Lanka's political and economic development.

\section{Conclusion}

Bridging human rights and political economy approaches has the potential to provide transformative gender justice that ensures the non-recurrence of conflict and violence by opening access to resources and social and economic sources of empowerment.

Transitional justice mechanisms can only redress inequalities and past grievances, but only to a certain extent when the government is reluctant to embrace these measures. Since the civil war ended in 2009 the Sri Lankan government has consistently voiced opposition to any form of international oversight of the local transitional justice processes. The result, as this paper has revealed, is that the local process has failed to deliver equitable and transitional justice let alone transformative justice. There remains no justice for the human rights and political opponents of the Rajapaska regime, the Tamil women and men detained on nothing more than suspicion of association with LTTE, and returned displaced women, many of whom are now single heads of households. Multiple reports confirm that these three groups have been consistently targeted for sexual violence for the purposes of intimidation and extortion since 2009. There is an obvious need for international actors to be involved in the local transitional justice process to ensure the government investigates these allegations against their security sector. Ending the impunity of the Sri Lanka security sector is vital for the LLRC to meet the recommendations that the Sirisena government agreed to at the Human Rights Council in September 2015. In a 
situation where the government appears reluctant to hold the security sector to account, the same sector that heavily relies upon the income stream from its continued militarisation of the North and East provinces, a measure open to the international community is to link security sector reform with foreign investment. Both sides of this conflict can claim trauma and atrocities but the victors have a particular responsibility to end the cycle of physical, gender and economic violence continuing in the North and East.

Broader economic, security sector, and political reform therefore must occur in tandem to strengthen the opportunities for diverse groups of women to participate in the governance of today and tomorrow at the local, provincial and national levels. The international community has an opportunity to build on the Sri Lanka government's desire to maintain its reputation as a 'middle income country at peace' attracting a diverse portfolio of foreign investors. That opportunity could be realised by linking economic development plans with redress for past crimes, gender-equality targets, and economic redistribution commitments especially in conflict-affected areas.

Closely examining the Sri Lanka case, in this paper we have highlighted the relationship between enduring structural gender inequalities and conflict and postconflict-related sexual and gender-based violence. In the absence of legal benchmarks to investigate and prosecute such violence, economic and political incentives are crucial for the vision of gender justice in conflict-affected and prone situations like Sri Lanka. An economic reparative approach may be the only option available but as essential as a justice reparative approach for the recognition and realisation of the full range of women's needs and capacities in post-conflict societies and for the non-recurrence of violence.

\footnotetext{
${ }^{1}$ Andrea Durbach and Louise Chappell, 'Leaving Behind the Age of Impunity', International Feminist Journal of Politics, 16:4 (2014), 543-462.

${ }^{2}$ Three main investigations by the United Nations (UN) have identified both the Government of Sri Lanka and the Liberation Tamil Tigers of Eelam (LTTE) as responsible for war crimes and crimes against humanity in the final stages of the war; and the Government of Sri Lanka for committing ongoing human rights violations in the aftermath of the war and failing to create a transparent and accountability transitional and reconciliatory justice process. Marzuki Darusman, Steven Ratner and Yasmin Sooka. Report of the Secretary-General's Panel of Experts on Accountability in Sri Lanka. 31 March 2011 (New York: United Nations); Charles Petrie. Report of the Secretary-General's Internal Review Panel on United Nations Action in Sri Lanka, November
} 
2012 (New York: United Nations); OHCHR Investigation on Sri Lanka (OISL). Report of the OHCHR Investigation on Sri Lanka (OISL). A/HRC/30/CRP. 16 September 2015 (Geneva: United Nations)

${ }^{3}$ Darusman, Ratner and Sooka. Report of the Secretary-General's Panel of Experts on

Accountability in Sri Lanka, 43.

${ }^{4}$ OHCHR, A/HRC/30/CRP, 117.

${ }^{5}$ OHCHR, A/HRC/30/CRP, 221-222; International Truth and Justice Project (ITJP). A Still Unfinished War: Sri Lanka's Survivors of Torture and Sexual Violence 2009-2015 (Johannesburg: Foundation for Human Rights South Africa, 2015), 5-6.

${ }^{6}$ OHCHR, A/HRC/30/CRP, 223, 229.

7 UN Secretary-General. Report on Conflict-related Sexual Violence, S/2013/149, 14 March 2013, 22.

8 OHCHR, A/HRC/30/CRP, 126; UN Secretary-General. Report on Conflict-related Sexual

Violence, S/2016/361, 22 June 2016, 26.

${ }^{9}$ UN Secretary-General. S/2016/361, para 13.

${ }^{10}$ Anuradha Mittal and Elizabeth Fraser. Waiting to Return Home: Continued Plight of the IDPs in Post-War Sri Lanka (Oakland: Oakland Institute, 2016).

https://www.oaklandinstitute.org/waiting-return-home-continued-plight-idps-post-war-srilanka

11 FOKUS Women. Shadow Report to the United Nations Committee on the Elimination of Discrimination Against Women. 66th Session February - March 2017 8th Periodic Review of Sri Lanka (Colombo: FOKUS Women, 2016), 12.

http://www.fokuskvinner.no/PageFiles/10516/FOKUS\%20Shadow\%20report\%20Sri\%20LAnk a.pdf; Centre for Policy Alternatives, Accountability and Reparations for Victims of Conflict-Related Sexual Violence in Sri Lanka. (Colombo: CPA, 2016). http://www.cpalanka.org/accountabilityand-reparations-for-victims-of-conflict-related-sexual-violence-in-sri-lanka; International Truth and Justice Project (ITJP). A Still Unfinished War: Sri Lanka's Survivors of Torture and Sexual Violence 2009-2015 (Johannesburg: Foundation for Human Rights South Africa, 2015), 5-6. 12 Nihal Jayawickrama, 'The Hybrid Court', Colombo Telegraph, 26 September 2015. https://www.colombotelegraph.com/index.php/the-hybrid-court/. 13 UNFPA. Protecting Women's Rights (Colombo: United Nations, 2016), 6-7. http://srilanka.unfpa.org/sites/asiapacific/files/pub-pdf/WomensRights.pdf ${ }^{14}$ FOKUS Women, Shadow Report, 66th Session, 12; UNFPA. Bringing generations together for our Sri Lanka (Colombo: United Nations, 2016), 8.

http://srilanka.unfpa.org/sites/asiapacific/files/pub-pdf/G2G\%20Voices.pdf

15 ITJP, A Still Unfinished War, 15-18, 25-26; OHCHR, A/HRC/30/CRP, 112, 127; CPA,

Accountability and Reparations, 7-8.

16 FOKUS Women. Post War Trends in Child Marriage

Sri Lanka (Colombo: FOKUS Women, 2015), 21-22.

http://www.fokuskvinner.no/PageFiles/9830/Post\%20War\%20Trends\%20in\%20Child\%20Ma rriage-English-15\%2005\%202015.pdf; UNFPA. Extent, Trends and Determinants of Teenage Pregnancies in Three Districts of Sri Lanka (Colombo: United Nations, 2012), 11.

${ }^{17}$ Fulu, E., Warner, X., Miedema, S., Jewkes, R., Roselli, T. and Lang, J. Why Do Some Men Use Violence Against Women and How Can We Prevent It? Quantitative Findings from the United Nations Multi-Country Study on Men and Violence in Asia and the Pacific (Bangkok: UNDP, UNFPA, UN Women and UNV, 2013), 45, 53.

http://www.partners4prevention.org/sites/default/files/resources/p4p-report.pdf

${ }_{18}$ Maithree Wickramasinghe and Chulani Kodikara. "Representation in Politics:

Women and Gender in the Sri Lankan Republic", in Asanga Welikala (ed) The Sri Lankan Republic at 40: Reflections on Constitutional History, Theory and Practice (Colombo: Centre for Policy Alternatives and Friedrich Naumann Stiftung für die Freiheit (FNF), 2012), 783.

http://republicat40.org/wp-content/uploads/2013/01/Representation-in-Politics1.pdf ${ }^{19}$ The use of the term gender-based violence is in contrast to other post-conflict states where sexual violence is major part of public and international discourse (sometimes leading to other everyday forms of violence such as domestic violence being overlooked). See UNFPA. Keeping the Promise to Women (Colombo: UNFPA, 2016)

http://srilanka.unfpa.org/sites/asiapacific/files/pub-

pdf/UNFPA\%20Gender\%20Brochure\%20V2.7.pdf 
${ }^{20}$ FOKUS Women. Whither Justice? The Language Barrier in Accessing The Criminal Justice System (Colombo: FOKUS Women, 2016). http://www.fokuswomen.lk/language-barrier/

${ }^{21}$ Chandrani Bandara. "Women in Post War Reconciliation 'The Road to Reconciliation: Justice, Hope and Dignity in Sri Lanka", Statement by Minister of Women and Child Affairs Hon. "Women in Post-Conflict Reconciliation - The Road to Reconciliation: Justice, Hope and Dignity in Sri Lanka", 17th March 2016 (New York). http://www.slmission.com/index.php/news/91latest/842-active-participation-by-sri-lanka-at-the-sixtieth-commission-for-the-status-ofwomen-csw-in-new-york-14-24-march-2016

22 CPA, Accountability and Reparations.

${ }^{23}$ Chulani Kodikara, 'Justice and Accountability for war related sexual violence in Sri Lanka', Open Democracy, 15 August 2016. https://www.opendemocracy.net/5050/chulani-kodikara/justiceand-accountability-for-war-related-sexual-violence-in-sri-lanka; Ram Manikkalingam, 'Politics of punishing war crimes in Sri Lanka', Open Democracy, 8 February 2016.

https://www.opendemocracy.net/openglobalrights/ram-manikkalingam/politics-of-punishingwar-crimes-in-sri-lanka

${ }^{24}$ Ambika Satkunanathan, "What is represented and what is made invisible": Women and Transitional Justice Processes in Sri Lanka', Groundviews, 3 June 2015.

http://groundviews.org/2015/06/03/what-is-represented-and-what-is-made-invisible-womenand-transitional-justice-processes-in-sri-lanka/

25 Uppsala Conflict Data Program, Sri Lanka, Accessed 1 August 2016. http://ucdp.uu.se/

${ }^{26}$ OHCHR, A/HRC/30/CRP, 219.

${ }^{27}$ Malatha de Alwis, "The "Purity" of Displacement and the Reterritorialization of Longing:

Muslim IDPs in Northwestern Sri Lanka", in Wenona Giles and Jennifer Hyndman (Eds) Sites of

Violence: Gender and Conflict Zones (Berkley: University of California Press, 2004), 217.

28 OHCHR, A/HRC/30/CRP, 12.

${ }^{29}$ OHCHR, A/HRC/30/CRP, 12-15.

${ }^{30}$ OHCHR, A/HRC/30/CRP, 13; Mark Salter, To End a Civil War: Norway's Peace Engagement in Sri Lanka (London: Hurst, 2015), Chapter 1.

${ }^{31}$ OHCHR, A/HRC/30/CRP, 2015, 219

32 OHCHR, A/HRC/30/CRP, 18.

${ }^{33}$ For the definition of widespread and systematic sexual and gender-based crimes see Office of the ICC Prosecutor. Policy paper on sexual and gender-based crimes, June 2014 (Hague: ICC), p.5. These crimes may occur in conflict or not. The OHCHR Investigation on Sri Lanka found SGBV was widespread, and violations by the Sri Lanka government security forces may amount to crimes against humanity and war crimes. OHCHR, A/HRC/30/CRP, 223.

${ }^{34}$ See Sooka, An Unfinished War, 78, 80; OHCHR, A/HRC/30/CRP, 117-128. Human Rights Watch, We will teach you a lesson: Sexual Violence against Tamils by Sri Lankan Security Forces, 26

February 2013. https://www.hrw.org/report/2013/02/26/we-will-teach-you-lesson/sexualviolence-against-tamils-sri-lankan-security-forces; International Truth and Justice Project. A Still Unfinished War: Sri Lanka's Survivors of Torture and Sexual Violence 2009-2015, July 2015, 15-18, 25-26.

35 OHCHR, A/HRC/30/CRP, 128-129.

36 OHCHR, A/HRC/30/CRP, 19.

${ }^{37}$ It remains unknown how many combatants and people suspected of having links to LTTE were detained in 2008 and 2009. It is known that there were summary executions and acts of torture and rape committed against detainees. Darusman, Ratner and Sooka, Report of the SecretaryGeneral's Panel of Experts, iii; OHCHR, A/HRC/30/CRP, 2015: 21.

${ }^{38}$ Human Rights Watch, We will teach you a lesson, 4.

${ }^{39}$ Human Rights Watch, We will teach you a lesson, 7.

40 OHCHR, A/HRC/30/CRP, 124-126.

${ }^{41}$ Petrie, Report of the Secretary-General's Internal Review Panel, 46. High Commissioner Pillay found little support within the Human Rights Council to adopt a resolution that forced the Sri Lanka government to adopt a national peace and reconciliation accord in 2009. The Human Rights Council adopted resolution S/11-1 27 on 27 May 2009 congratulating the Sri Lankan government for its victory. Petrie, Report of the Secretary-General's Internal Review Panel, 96. 42 Petrie, Report of the Secretary-General's Internal Review, 89.

${ }^{43}$ Darusman, Ratner and Sooka, Report of the Secretary-General's Panel of Experts, 44, 47, 50

${ }^{44}$ Darusman, Sooka and Ratner, Report of the Secretary-General's Panel of Experts, $\mathrm{v}$ 
${ }^{45}$ Darusman, Ratner and Sooka, Report of the Secretary-General's Panel of Experts, 17; Human Rights Watch, Breaking the Silence, 6

${ }^{46}$ Human Rights Watch, We will teach you a lesson, 2013.

${ }^{47}$ Sooka, An Unfinished War, 45; International Truth and Justice Project, A Still Unfinished War, 6.

48 OHCHR, A/HRC/30/CRP, 117-128.

${ }^{49}$ Petrie, Report of the Secretary-General's Internal Review, 16

${ }^{50}$ International Truth and Justice Project, A Still Unfinished War, 7.

${ }^{51}$ OHCHR, A/HRC/30/CRP, 223.

52 British Broadcasting Corporation, 'Four Sri Lankan soldiers convicted of raping Tamil woman', 7 October 2015. http://www.bbc.com/news/34470053

${ }_{53}$ Asian Tribune, 'Sri Lanka's Presidential Election 'Momentous' - Foreign Minister Bogollagama', 28 January 2010. http://www.asiantribune.com/news/2010/01/29/sri-lanka\%E2\%80\%99spresidential-election-\%E2\%80\%98momentous\%E2\%80\%99-\%E2\%80\%93-foreign-ministerbogollagama

54 The Economist, "Last days of the Raj?," 3 January 2015.

http://www.economist.com/news/leaders/21637389-encouragingly-mahinda-rajapaksa-facesreal-battle-win-re-election-president-better

55 Premachandra Athukorala and Sisira Jayasuriya. 'Victory in War and Defeat in Peace: Politics and Economics of Post-Conflict Sri Lanka', Asian Economic Papers 14:3 (2015), 22-54.

56 Transparency International. Sri Lanka National Integrity System Assessment 2014.

http://www.transparency.org/whatwedo/publication/sri_lanka_national_integrity_system_asses sment_2014. Accessed 1 August 2016; Verite Research. Sri Lanka: LLRC Implementation Monitor, Statistical and Analytical Review No.4, (Colombo: Verite Research, 2016).

${ }^{57}$ See http://www.worldbank.org/en/country/srilanka..

58 International Crisis Group, The Forever War?, 25 March 2014.

http://blog.crisisgroup.org/asia/2014/03/25/the-forever-war-military-control-in-sri-lankasnorth/

59 Verite, Sri Lanka, 7.

${ }^{60}$ Ministry of Defence. Report of the Commission of Inquiry on Lessons Learnt and Reconciliation (Colombo: Sri Lanka Government, 2011), paras 9.86, 9.87.

61 International Crisis Group, 'Sri Lanka: Women's Insecurity in the North and East', Report 217

(Asia) (Brussels/Colombo: ICG, 2011). https://www.crisisgroup.org/asia/south-asia/srilanka/sri-lanka-women-s-insecurity-north-and-east; FOKUS Women. Shadow Report, 15-18.

${ }^{62} \mathrm{~A}$ higher presence of FHH in the Northern and Eastern provinces is likely attributable to the war because the proportion of FHH categorised as separated/divorced/widowed is around 80 per cent in those provinces (with few married or never married female heads compared with other provinces) The Department of Census and Statistics, 2012-13 Household Income and Expenditure Survey (Colombo); UNFPA, Protecting Women's Rights, 4.

${ }^{63}$ FOKUS Women, Whither Justice?

${ }^{64}$ International Crisis Group, The Forever War?, 25 March 2014; Verite Research, Sri Lanka, 14.

65 Wickremesinghe, Report Of The Leader Of The Opposition.

${ }^{66}$ Wickremesinghe, Report Of The Leader Of The Opposition, 39.

${ }^{67}$ Wickremesinghe, Report of The Leader Of The Opposition, 36.

${ }^{68}$ Consultation Taskforce, Interim Report, 14.

${ }^{69}$ Ranil Wickremesinghe, Report Of The Leader Of The Opposition's Commission On The Prevention Of Violence Against Women And The Girl Child, December 2014, 7. http://www.childwomenmin.gov.lk/resources/30/REPORT.pdf.

${ }^{70}$ Fokus Women. A Report on the Status of Female Heads of Households and their Access to Economic, Social and Cultural Rights 2015 (Colombo: FOKUS Women, 2015).

${ }^{71}$ Ministry of Defence, Report of the Commission of Inquiry, para.5.103, citing a report dated 21 September 2011 received from the Ministry of Child Development and Women's Affairs. See also FOKUS Women. Shadow Report to the United Nations Human Rights Committee. 112th Session 731 $1^{\text {st }}$ October, 2014 (Colombo: FOKUS Women), 4.

${ }^{72}$ Consultation Taskforce, Interim Report, 36.

${ }^{72}$ Consultation Taskforce, Interim Report, 16.

${ }^{73}$ CEPA. "Samurdhi Unpacked: Selecting Beneficiaries." Development Dialogue. Financial Review, 18 May 2016.

${ }^{74}$ Consultation Taskforce, Interim Report, 16. 
75 Department of Census and Statistics, Annual Labour Force Survey 2011, 2012, 2013, \& 2014, Colombo. http://www.statistics.gov.lk/page.asp?page=Labour\%20Force.

${ }^{76}$ M. Saravanathan, The Pains of Labour: in the Post-Civil War Development in the City of Jaffna, Northern Province, Sri Lanka, 2016. Report prepared for the Solidarity Center in Sri Lanka (Colombo: Point Pedro Institute of Development, 2016), 6.

77 Center for Poverty Analysis (CEPA). "The political economy of women's economic relations in post-war Sri Lanka." SLRC Working Paper (Colombo: CEPA, 2016).

http://www.securelivelihoods.org/publications_details.aspx?resourceid $=426$

${ }^{78}$ IRIN. Fewer "I do's" for former female rebels, 23 February 2011.

http://www.irinnews.org/report/92017/sri-lanka-fewer-i-dos-former-female-rebels

${ }^{79}$ See Sri Lanka Government rehabilitation program for 12,000 ex-LTTE combatants report here http://www.bcgr.gov.lk/docs/Rehabilitation\%20of\%20Ex-Combatants\%20(Compiler\%20\%20Brigadier\%20Dharshana\%20Hettiarrachchi).pdf

${ }^{80}$ Sri Lanka Government. "Programmes implemented related to policy matter 2015", Ministry of Women and Child Affairs. http://www.childwomenmin.gov.lk/English/institutes/nationalcommittee-on-women/policy; Verite Research, The President's Pledges to Women, A review of the promises and progress made in President Sirisena's pledge: "A New Sri Lanka for Women", (Colombo: Verite Research, 2016).

${ }^{81}$ Saravanathan, The Pains of Labour, 29

82 Verite, Sri Lanka, 15.

${ }^{83}$ Sri Lanka Government. "National Committee on Women, Ministry of Women and Child Affairs" http://www.childwomenmin.gov.lk/English/news/ministry-news/national-framework-

andnationalactionplan

${ }^{84}$ Verite, The President's Pledges to Women, 19.

85 Ibid.

${ }^{86}$ OHCHR, A/HRC/30/CRP, 25.

87 OHCHR, A/HRC/30/CRP , 117.

${ }^{88}$ Sri Lanka co-sponsored Resolution 30/1 at the 30th Session of the United Nations Human Rights Council. Verite, Sri Lanka, 1.

${ }^{89}$ Verite, Sri Lanka.

${ }^{90}$ Sri Lanka Government. "Secretariat for Coordinating Reconciliation Mechanisms". Website. http://www.scrm.gov.lk/\#!consultations/cjg9

${ }^{91}$ Consultation Taskforce, Interim Report.

${ }_{92}$ Consultation Taskforce, Interim Report.

${ }_{93}$ In May 2016 a bill on the establishment of an Office of Missing Persons was put forward in the Parliament.

94 See Malin Jordal, Kumudu Wijewardena, and Pia Olsson. Unmarried women's ways of facing single motherhood in Sri Lanka - a qualitative interview study, BMC Womens Health 13: 5 (2013); Malathi de Alwis, 'Housewives of the Public' The Cultural Signation of the Sri Lankan Nation, in Ilse Lenz, Helma Lutz, Mirjana Morokvasic-Muller, Claudia Schöning-Kalender and Helen Schwenken (eds.), Crossing Borders and Shifting Boundaries: Vol. II: Gender, Identities

(Amsterdam: Springer, 2013), 21.

${ }^{95}$ Saravanathan, The Pains of Labour, 29.

${ }^{96}$ Consultation Taskforce, Interim Report, 16.

${ }_{97}$ Consultation Taskforce, Interim Report, 39.

98 Jacqui True, The Political Economy of Violence Against Women (New York: Oxford University Press, 2013) 77-94.

${ }^{99}$ Alan Keenan, "Impunity and Justice: Why the UN Human Rights Council Must Stay Engaged in Sri Lanka", In Pursuit of Peace International Crisis Group Blog, 17 June 2016.

http://blog.crisisgroup.org/asia/2016/06/17/impunity-and-justice-why-the-un-human-rightscouncil-must-stay-engaged-in-sri-lanka/ 